\title{
MONETARY POLICY TRANSPARENCY AND FINANCIAL MARKET FORECASTS IN SOUTH AFRICA
}

\author{
Vivek Arora \\ International Monetary Fund \\ varora@imf.org
}

June 2007

\begin{abstract}
The transparency of monetary policy in South Africa has increased substantially since the end of the 1990s. But little empirical work has been done to examine the economic benefits of the increased transparency. This paper shows that, in recent years, South African private sector forecasters have become better able to forecast interest rates, are less surprised by reserve bank policy announcements, and are less diverse in the cross-sectional variety of their interest rate forecasts. In addition, there is some evidence that the accuracy of inflation forecasts has increased. The improvements in interest rate and inflation forecasts have exceeded those in real output forecasts, suggesting that increases in monetary policy transparency are likely to have played a role.
\end{abstract}

\section{Keywords:}

Monetary policy, transparency, financial market forecasts, South Africa

This article was originally published as Monetary Policy Transparency and Financial Market Forecasts in South Africa (IMF WP/07/123) by Vivek Arora.

(C) International Monetary Fund, 700 19th Street, NW, Washington, DC 20431, USA.

The views expressed in this article belong solely to the author. Nothing contained in this article should be reported as representing IMF policy or the views of the IMF. 


\section{INTRODUCTION}

As in other areas of economic policy in South Africa, the framework for monetary policy formulation has changed substantially since the end of apartheid in 1994. A significant development has been an increase in monetary policy transparency as institutional changes have been introduced to make policy more transparent and accountable, particularly with the adoption of an inflation targeting framework in 2000. An important question for research, and one that has received little attention in the literature to date, is what the economic benefits of the greater policy transparency have been. Aron and Muellbauer (2005) provide a comprehensive review of the post-1994 South African monetary policy experience and related literature; Mboweni (2004) and Van der Merwe (2004) outline the main measures that have been taken to increase monetary policy transparency since 2000 . This paper contributes to the literature by examining the implications of the increase in South African monetary policy transparency for the accuracy of private sector financial forecasts, which is an indicator of expectations formation and a measure of the benefits of greater transparency.

Several papers in the literature have analysed the implications of greater monetary policy transparency in other countries. A key benefit of greater monetary policy transparency is that, by reducing policy uncertainty, it can have a positive impact on the accuracy of private sector financial forecasts. Greater forecast accuracy in turn allows private agents to take a longerterm view of economic decisions than they could do otherwise, strengthening the basis for investment and employment creation. Swanson (2006) shows that, since the 1980s, US financial markets and private sector forecasters have become better able to forecast the federal funds rate and are less surprised by Federal Reserve announcements, in part due to greater Federal Reserve transparency.

In many countries, including South Africa, greater monetary transparency has been associated with the adoption of an inflation targeting framework. There is some debate in the literature about the implications of adopting inflation targeting. Bernanke (1999) and others provide evidence that inflation and inflation expectations in inflation-targeting countries have fallen by more than could have been predicted ex ante. Ball and Sheridan (2003) and others argue, however, that countries that adopt inflation targeting tend to have experienced inflation rates that are higher than historical averages in the preceding period, and once one allows for mean reversion there is no evidence that the adoption of inflation targeting has any impact on inflation dynamics. The present paper does not enter directly into this discussion, as it focuses on the impact of monetary transparency in general rather than that of inflation targeting in particular.

The analysis follows the approach of Swanson (2006) and focuses on the private sector's ability to forecast interest rates. While the focus of Swanson (2006) was on the fed funds rate, the analysis in the present paper focuses on market interest rates. The central conclusion, based on monthly data for 1997-2006, is that the accuracy of private sector interest rate forecasts has increased significantly. In addition, in the more recent period financial market surprises around MPC announcements have been reduced and the dispersion across different private sector forecasts has fallen. The evidence also indicates some improvement in the accuracy and dispersion of inflation forecasts. The improvements in private sector interest rate forecasts have exceeded those in output forecasts, suggesting that increases in monetary policy transparency may have played a role. 


\section{INCREASES IN MONETARY POLICY TRANSPARENCY}

Monetary policy transparency in South Africa has increased significantly during the postapartheid period and particularly after 1999 (TABLE 1).

TABLE 1: Selected changes in SARB transparency, 1994-2006

\begin{tabular}{|c|c|}
\hline Date & Selected change in SARB transparency \\
\hline 1996 & $\begin{array}{l}\text { Existence and extent of SARB foreign exchange forward book disclosed. } \\
\text { Thereafter, details of net open forward position regularly published. }\end{array}$ \\
\hline October 1999 & $\begin{array}{l}\text { Establishment of a Monetary Policy Committee (MPC). MPC to meet every 6-8 } \\
\text { weeks; policy statements published. }\end{array}$ \\
\hline February 2000 & $\begin{array}{l}\text { Adoption by government of inflation target for the SARB to implement (3-6 } \\
\text { percent annual average by 2002). }\end{array}$ \\
\hline February 2000 & $\begin{array}{l}\text { Introduction of monetary policy forums convened by SARB. Held twice yearly in } \\
\text { major financial centres and attended by labour, business, government, and } \\
\text { academic representatives. }\end{array}$ \\
\hline March 2001 & $\begin{array}{l}\text { Introduction of Monetary Policy Review (MPR), published twice yearly. MPR } \\
\text { includes SARB's inflation forecast fan chart. }\end{array}$ \\
\hline 2002 & Frequency of MPC meetings reduced to 4 times yearly. \\
\hline May 2003 & Frequency of MPC meetings increased to 6 times yearly. \\
\hline November 2003 & $\begin{array}{l}\text { Refinement of inflation target from annual (average) basis to continuous basis } \\
\text { (12-month rate). }\end{array}$ \\
\hline
\end{tabular}

Source: Van der Merwe (2004); National Treasury Medium Term Budget Policy Statements (various issues)

In the period after 1994, the South African Reserve Bank (SARB) gradually increased the amount of information that it disclosed about its operations. After 1996, it started to publish information about its forward book in foreign exchange. The increases in transparency became more pronounced with the establishment in 1999 of a monetary policy committee, which would meet regularly and publish the conclusions of its meetings, and the adoption in 2000 of an inflation target to become effective in 2002. Monetary policy forums were introduced in 2000 that are conducted on a semi-annual frequency and allow for an exchange of views on monetary policy between the SARB and the public. A bi-annual publication, the Monetary Policy Review, was introduced in 2001 that presents the SARB's views on monetary developments and the inflation outlook.

\section{ACCURACY OF FINANCIAL MARKET FORECASTS}

\subsection{Interest rate forecasts}

Greater monetary policy transparency should contribute to greater accuracy over time in private sector forecasts of interest rates, as the reserve bank's policy intentions become clearer to the public. A simple measure of the accuracy of private sector interest rate forecasts is the 
deviation between the actual outturn of the spot rate on a given date and the market prediction of that outturn made at a previous date. The market prediction in turn can be captured by the forward rate that prevailed at the previous date. The accuracy of 3-month-ahead forecasts, for example, can be measured by the difference between the outturn in a given month and the 3 month forward rate that prevailed three months previously.

This measure of the forecast error is common in the literature. In principle, the forecast error can also be measured in percentage, not percentage-point, terms to reflect the belief that a given absolute error is a "bigger mistake" at lower than at higher actual rates. However, the conventional measure can be justified by the fact that central banks tend to move rates by relatively constant amounts (e.g., 25-50 basis points) over a wide range of actual rates, so that a given absolute error is of roughly equal significance across a range of actual rates. In any event, the trends that are reported below are qualitatively unchanged if the forecast errors are computed in percentage rather than percentage-point terms.

On this basis, the absolute value of interest-rate forecast errors declined during 1997-2006 (TABLE 2 and FIGURES 1-3).

TABLE 2: Time Series for Absolute forecast Error in JIBAR (annual averages, in basis points)

\begin{tabular}{lccc}
\hline Years & \multicolumn{3}{c}{$\begin{array}{c}\text { Errors at horizons of } \\
\text { 6 months }\end{array}$} \\
\hline 1997 & 0.72 & 1.11 & 12 months \\
1998 & 2.89 & 4.09 & 2.26 \\
1999 & 0.95 & 2.24 & 3.93 \\
2000 & 0.50 & 1.08 & 3.80 \\
2001 & 0.40 & 0.60 & 3.04 \\
2002 & 0.70 & 1.43 & 1.95 \\
2003 & 0.79 & 1.28 & 2.05 \\
2004 & 0.48 & 0.82 & 1.88 \\
2005 & 0.25 & 0.26 & 1.46 \\
2006 & 0.23 & 0.64 & 1.56 \\
\hline
\end{tabular}

Sources: Published JIBAR and FRA rates

FIGURES 1-3 plot the absolute value of the forecast error in the Johannesburg Interbank Average Rate (JIBAR), defined as the average realised spot value of the JIBAR in a given month minus the forward rate forecast of the JIBAR made 3, 6, and 12 months ago. The data are monthly averages calculated from daily spot and forward rates. Each of the three figures shows an increase over time in the accuracy of the forward market forecast of the JIBAR rate, reflected in a negative trend in the forecast errors. As one might expect, the proportionate decline in forecast errors was greater at shorter horizons. The average 3 -month-ahead forecast error declined by nearly two-thirds, from 126 basis points during 1997-2000 to 47 basis points during 2001-2006. The average 6-month-ahead and 12-month-ahead errors declined from 213 basis points and 326 basis points, respectively, during 1997-2000 to 84 and 159 basis points during 2001-2006. 
FIGURE 1: JIBAR 3-month-ahead forecast errors (absolute value, in basis points), 1997-2006

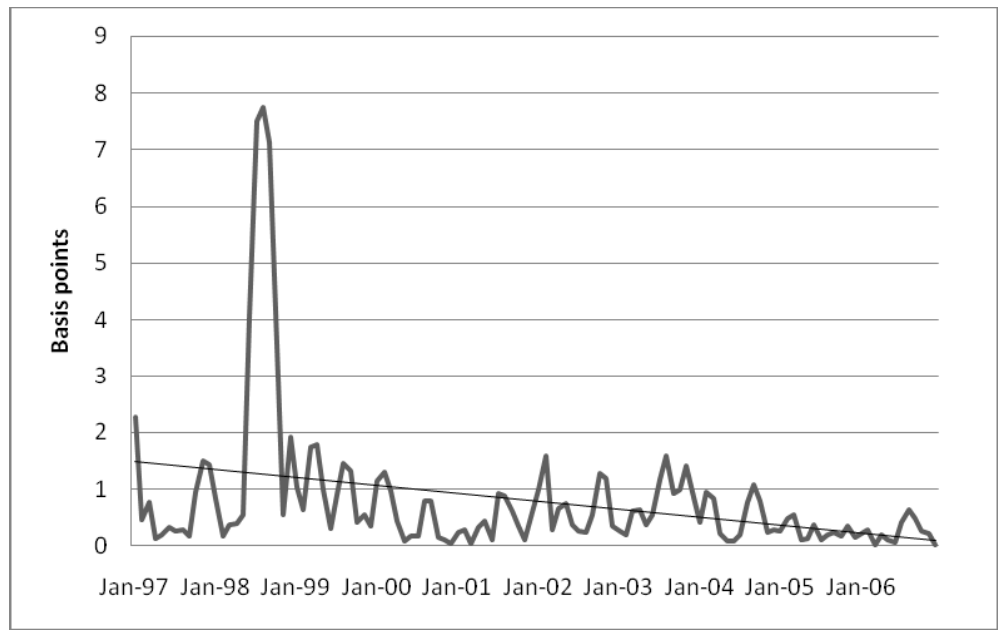

Source: Author's calculations, based on market data (see Appendix)

FIGURE 2: JIBAR 6-month-ahead forecast errors (absolute value, in basis points), 1997-2006

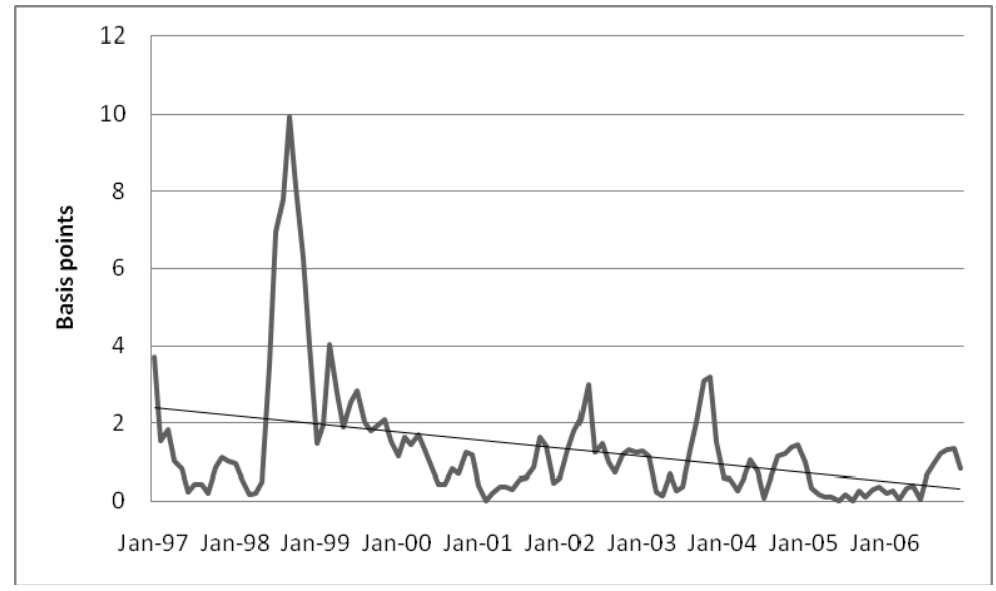

Source: Author's calculations, based on market data (see Appendix). 
FIGURE 3: JIBAR 12-month-ahead forecast errors (absolute value, in basis points), 1997-2006

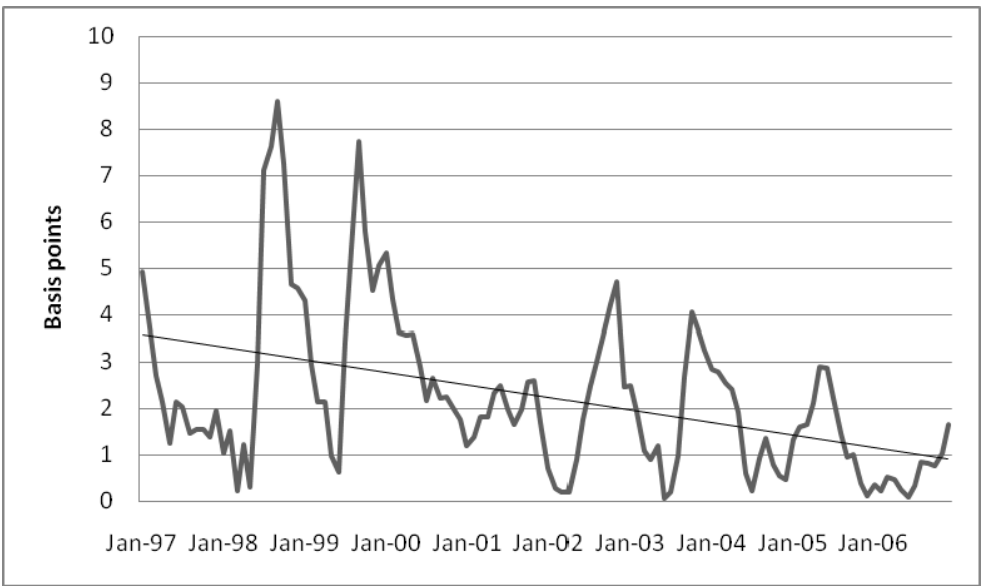

Source: Author's calculations, based on market data (see Appendix).

In 1998 and 2002, significant exogenous shocks, in addition to monetary policy effects, affected South African financial markets. In 1998, the uncertainty in global financial markets leading up to the Russian devaluation and the collapse of Long Term Capital Management (LTCM) contributed to a reduction in investors' appetite for assets in emerging markets, including South Africa. Market perceptions of the riskiness of South African assets were heightened by a buildup in the SARB's net open forward position (NOFP) as a result of foreign exchange intervention to support the currency. The impact on financial markets was evidenced most starkly in the exchange rate, which lost 17 percent of its value (in nominal effective terms) during MayAugust 1998. In late 2001, a shock reflecting both external and domestic factors contributed to a 20-percent decline in the value of the rand between September 2001 and September 2002. These episodes are discussed by Bhundia and Ricci (2005).

The decline in forecast errors was interrupted by the 1998 and 2002 episodes. The size of the increase in errors was smaller in 2002 than in 1998, which could mean that the size of the shocks was greater in 1998 or that the different policy responses to the two episodes had an influence on the size of the forecast errors. It is generally accepted that the policy response in 2002 was more conducive to macroeconomic stability than the response in 1998 (IMF, 2002). In addition, sovereign spreads widened substantially during the 1998 episode but did not do so in the 2001 episode, reflecting in part the positive perceptions of the soundness of macroeconomic policies in the intervening years. In any event, during 1999-2000 (a period that excludes the large errors in 1998 that are evident in FIGURES 1-3) the forecast errors at the three horizons were, respectively, 72 basis points, 166 basis points, and 342 basis points. The change in average forecast errors between 1999-2000 (as opposed to 1997-2000) and 2001-2005 was thus less steep, but it remained markedly negative at all horizons.

The negative trend in the forecast errors during 1997-2006 was statistically significant at the 3month and 6-month horizons (TABLE 3). 
TABLE 3: JIBAR Forward Market Forecast Errors, 1997:1-2006:12, (monthly data)

\begin{tabular}{cccc}
\hline Sample period & Constant & Time trend & Post-2001 dummy \\
\hline (a) 3-month-ahead error & & & \\
$1997-2001$ & $1.78(4.17)$ & $-0.022(-1.85)$ & \\
$1997-2006$ & $1.60(6.61)$ & $-0.017(-2.72)$ & $0.41(0.95)$ \\
(b) 6-month-ahead error & & & \\
$1997-2001$ & $2.67(4.99)$ & $-0.028(-1.81)$ & \\
$1997-2006$ & $2.53(8.05)$ & $-0.023(-2.86)$ & $0.44(0.78)$ \\
(c) 12-month-ahead error & & & \\
$1997-2001$ & $3.24(6.32)$ & $-0.008(-0.55)$ & \\
$1997-2006$ & $3.47(10.51)$ & $-0.016(-1.84)$ & $-0.55(-0.94)$ \\
\hline
\end{tabular}

* $t$-statistics in parentheses; forecast error measured in basis points; time trend in months

\section{Source: Author's regressions}

The negative trend was not statistically significant for the first half of the period, 1997-2001, but became so when the second half of the period was included, implying that forecasting accuracy increased during the more recent period. (The time trend in the 3-month and 6-month errors remains negative and statistically significant even if the sample period is limited to 19992006 and thus excludes 1998, when forecast errors were subject to significant exogenous shocks.) The trend was negative but not statistically significant at the 12-month horizon. A dummy variable for the post-2001 period was not statistically significant, which could capture the fact that although inflation targeting became effective in 2002, the associated changes in monetary transparency were part of an ongoing process and not identifiable with any discrete point in time.

That forecast errors declined during a time of "structural changes" may at first not be intuitive, because information about structural changes is usually only available with a lag and in any case not all forecasters may be immediately convinced that the observed changes are permanent. However, an increase in monetary policy transparency is different from many kinds of "structural change" because it should increase, not decrease, predictability. The information (by definition) is available with virtually no lag, since it comprises a series of announcements. And, as policy becomes more transparent, the SARB's intentions should become clearer over time. If these intentions gain credibility, then this should be reflected in a trend decline in forecast errors. Of course, forecast errors will still persist, and they will sometimes be large - reflecting the effects of shocks, inability to pick up turning points, other structural changes, policy surprises, or just plain bad forecasting - but they should show a trend decline over time. The evidence supports this characterisation for South Africa.

\subsection{Surprise component of MPC announcements}

As monetary policy becomes more transparent, the increase in public knowledge about the policy path intended by the reserve bank should presumably contribute to policy becoming more 
predictable and to market participants being less surprised by policy announcements over time. If a policy change is anticipated perfectly, then the announcement that effects it should have no immediate impact on market interest rates; but if a policy change surprises the markets it should induce a change in interest rates. (For further discussion, see Poole, Rasche \& Thornton, 2002.) The "surprise component" of MPC policy announcements can thus be measured by the change in market interest rates between the day immediately after and the day immediately before MPC meetings.

FIGURE 4: Fluctuations in the JIBAR Rate around MPC Announcement Dates, 1999-2006 (absolute value, in basis points, based on daily data)

FIGURE 4a: 3-month JIBAR fluctuations

1999-2006
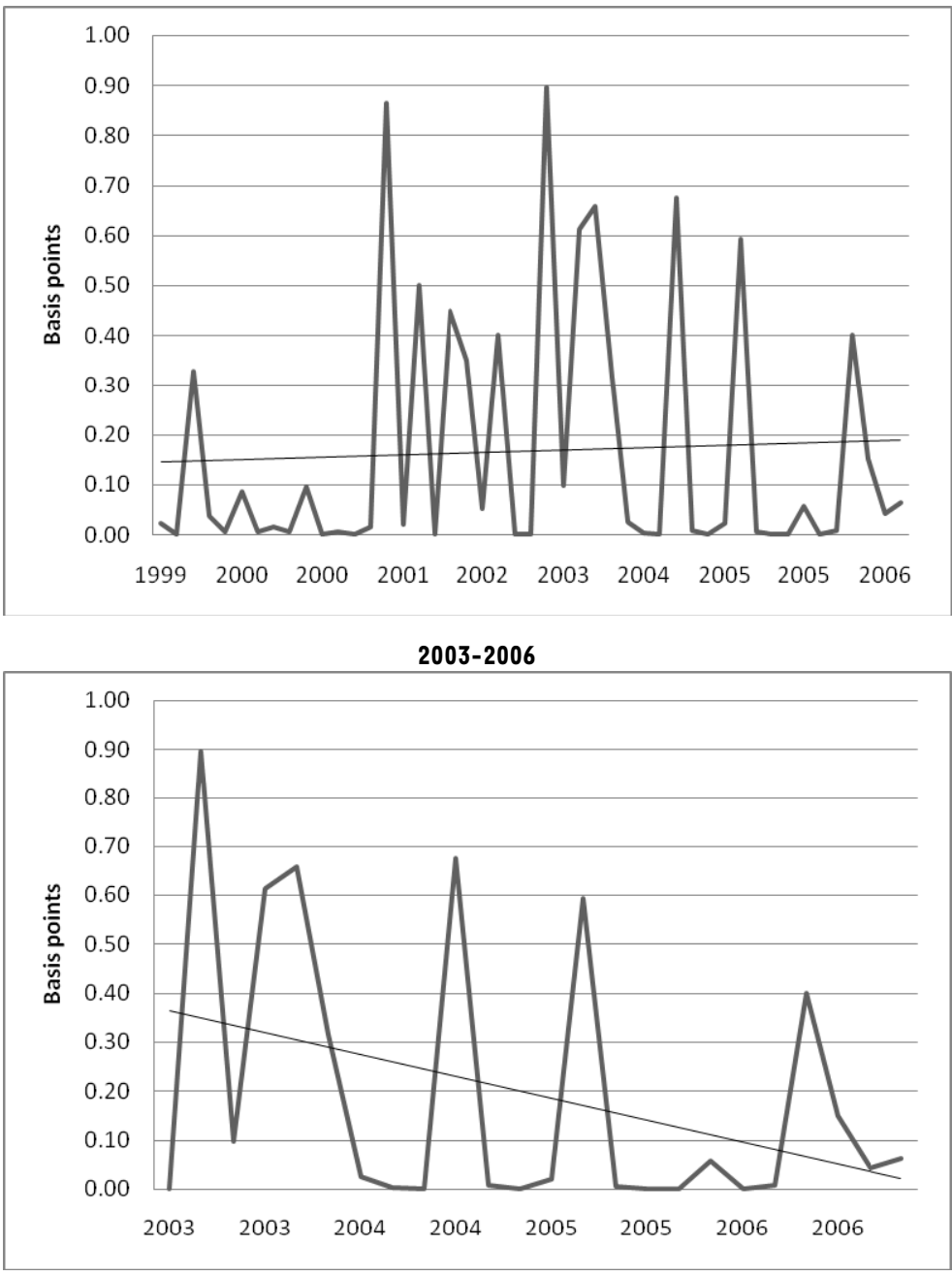

FIGURE 4 plots the absolute value of the surprise component of MPC policy announcements, as measured by changes in the 3 -month and 1 -month JIBAR rates (FIGURES $\mathbf{4 a}$ and $\mathbf{4 b}$ ) around each 
announcement date.

The top figure in each panel plots the surprise component during 1999-2006, a period during which there were 47 policy announcements. The surprise component turns out to have a slight upward trend, which can, however, be attributed to two large surprises in 2003 (in June and October). Excluding these two surprises, the average surprise associated with MPC announcements remained roughly unchanged, moving from 12 basis points (1-month) and 14 basis points (3-month) during October 1999 - March 2003 to 13 points and 14 points, respectively, during December 2003 - December 2005. For the full 2003-2005 period, the trend in the surprise component was markedly negative, as shown in the bottom panels of FIGURES $\mathbf{4 a}$ and $\mathbf{4 b}$.

FIGURE 4b: 1-month JIBAR fluctuations

1999-2006
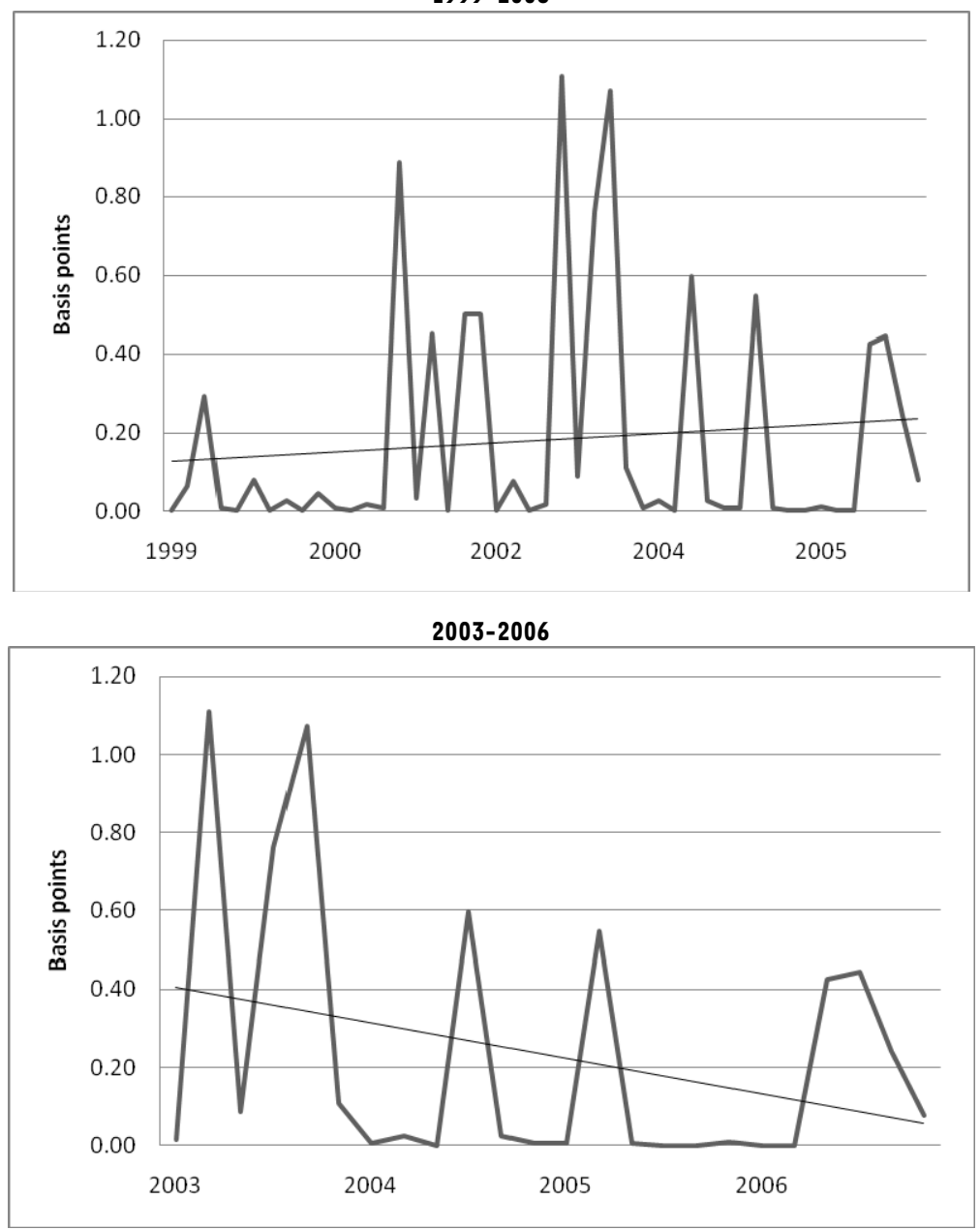
Figure 4c: Forward rate (1x4 FRA) fluctuations
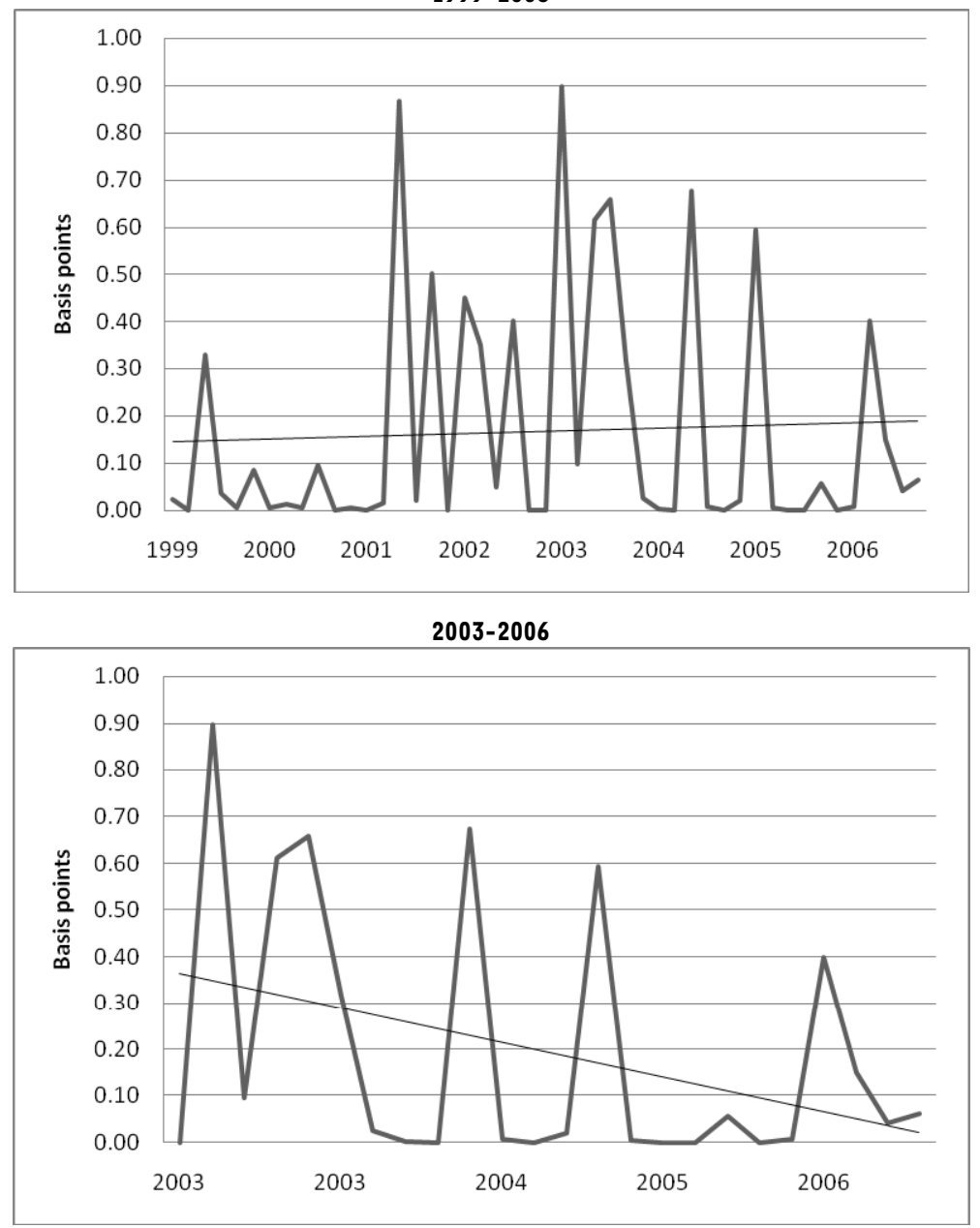

Source: Author's calculations based on market data (see Appendix)

This pattern was repeated in the surprise component measured by the JIBAR forward rate instead of the spot rate (FIGURE 4c).

The negative trend in the surprise component during 2003-2006 was statistically significant at the 10 -percent level for the 3 -month JIBAR rate and at the 5 -percent level for the forward rates (TABLE 4). 
TABLE 4: Surprise Component of MPC Announcements, 2003-2006 (based on daily data)

\begin{tabular}{lcc}
\hline \multicolumn{1}{c}{ Interest rate measure } & Constant & Time trend \\
\hline (a) 3-month JIBAR & $0.37(3.36)$ & $-0.015(1.89)$ \\
(b) 1-month JIBAR & $0.42(2.95)$ & $-0.015(1.51)$ \\
(c) Forward rate & $0.40(3.86)$ & $-0.016(2.23)$ \\
\hline
\end{tabular}

* $t$-statistics in parentheses

\section{Source: Author's regressions}

The trend in the surprise component for the 1-month rate was negative but not statistically significant. These results are, however, based on a small sample size, since the number of MPC announcements during the period was 24 .

\subsection{Dispersion of interest rate forecasts}

The increase in the accuracy of market forecasts of interest rates was accompanied by greater unanimity among forecasters, reflected in a reduction in the cross-sectional dispersion of forecasts. The dispersion, defined as the maximum - minus the minimum forecast of the prime rate in the Reuters monthly survey of market participants, declined over time at both the 1quarter ahead and 4-quarters-ahead horizons (FIGURE 5).

\section{FIGURE 5: Cross-sectional dispersion in interest rate forecasts}

\section{FIGURE 5a: 1-quarter-ahead forecasts}

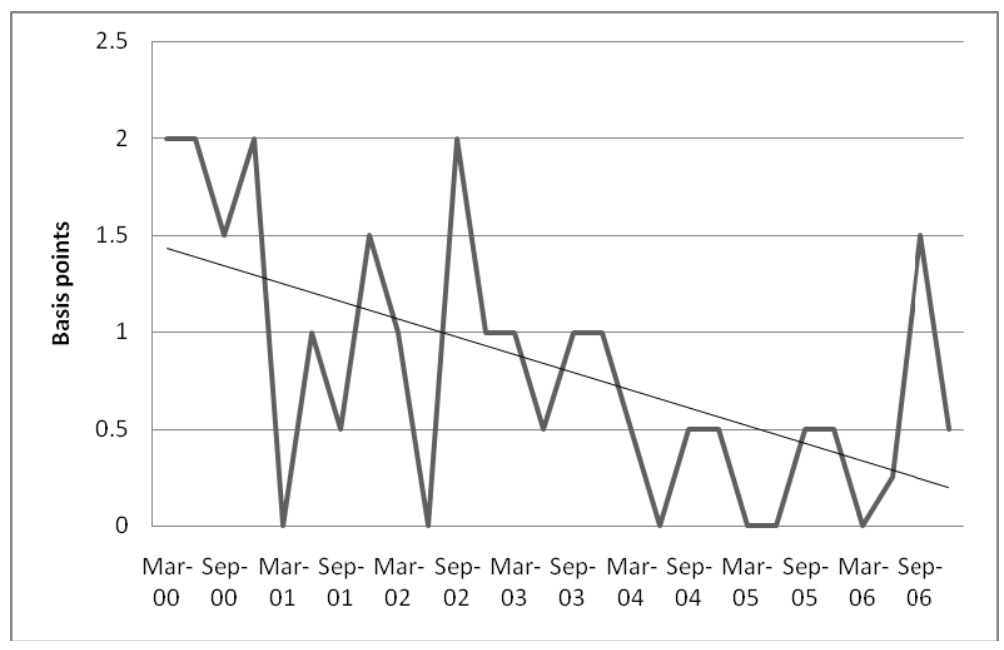


FIGURE 5b: 4-quarter-ahead forecasts

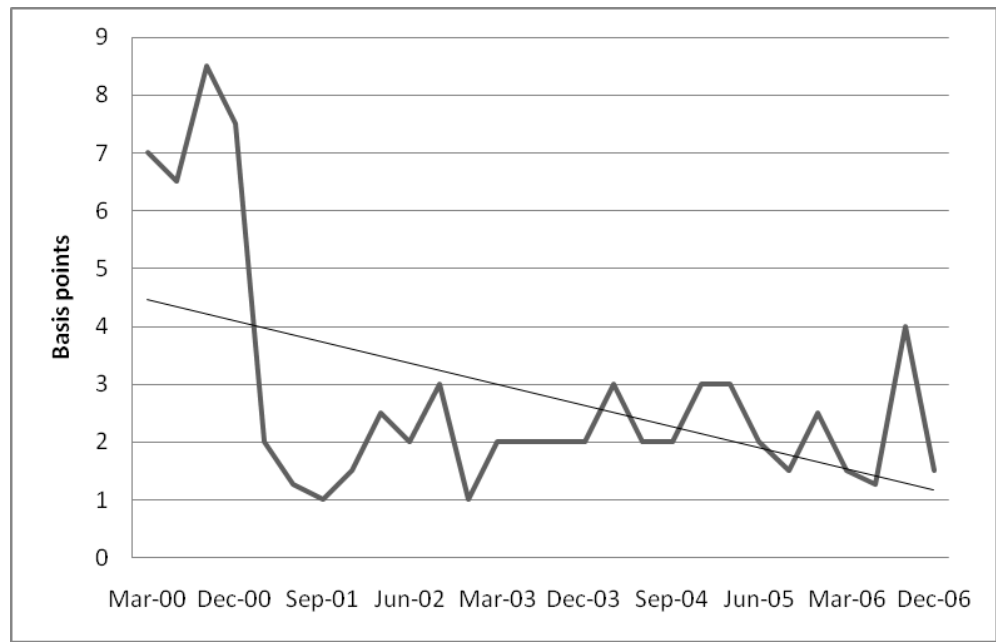

Source: Author's calculations, based on market data (see Appendix)

The negative trend in the cross-sectional dispersion of forecasts was statistically significant at the 5-percent level (see TABLE 5).

TABLE 5: Forecast dispersion, March 2000-December 2006 (dependent variable: forecasts of the prime rate, quarterly data)

\begin{tabular}{lcc}
\hline & Corecast horizon & Time trend \\
\hline (a) 1 quarter & 1.47 & -0.05 \\
& $(6.63)$ & $(-3.41)$ \\
(b) 4 quarters & 4.59 & -0.12 \\
& $(6.58)$ & $(-2.91)$ \\
\hline
\end{tabular}

* $t$-statistics in parentheses

Source: Author's regressions

Could the negative trend in forecast dispersion simply reflect nothing more than a "herd mentality" as, with a growing number of surveys being conducted, forecasters are able (and arguably even induced to) converge towards a common consensus view based on the information available from the various surveys? In fact, it is difficult to see how such a herd mentality could persist in the absence of an actual increase in the predictability of rates, since there is no reason to expect that forecasts made by profit-maximizing firms will converge to a "wrong" value for very long. Indeed, the decline in forecast dispersion alongside the decline in forecast errors is more consistent with an increase in the predictability of monetary policy. Moreover, the evidence in this paper suggests that forecast dispersion has declined over time in the same survey (the Reuters survey of forecasters). 


\subsection{Inflation trends}

Inflation has declined markedly over the past decade, with the average CPI inflation rate in 2006 (41/2 percent) lower by one-third against its 1996 level (FIGURE 6).

\section{FIGURE 6: Inflation trends (12-month change, in percent)}

CPI, 1996-2006

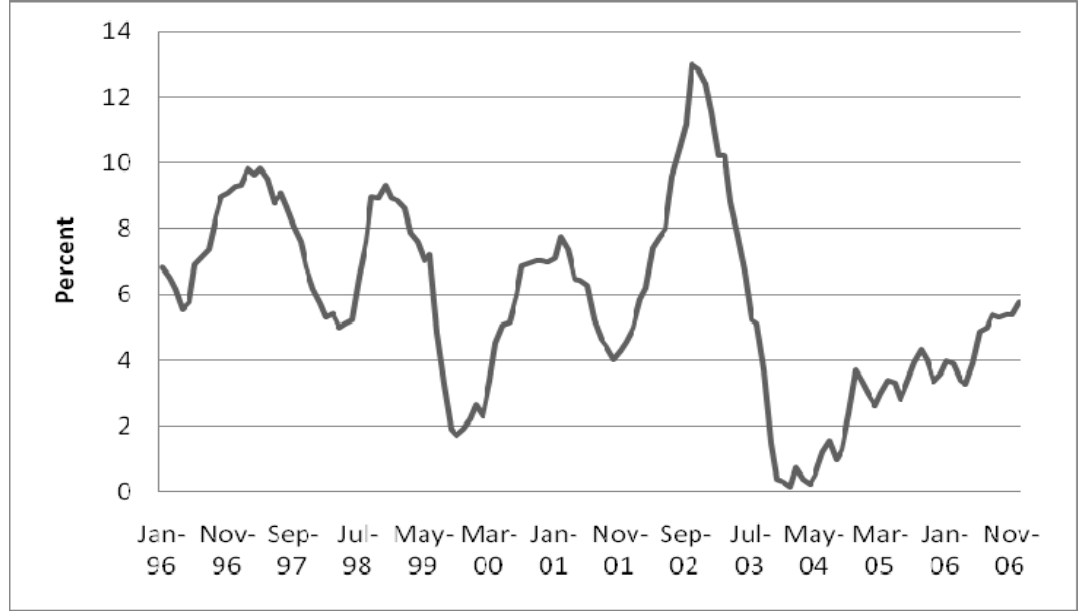

CPIX, 1998-2006

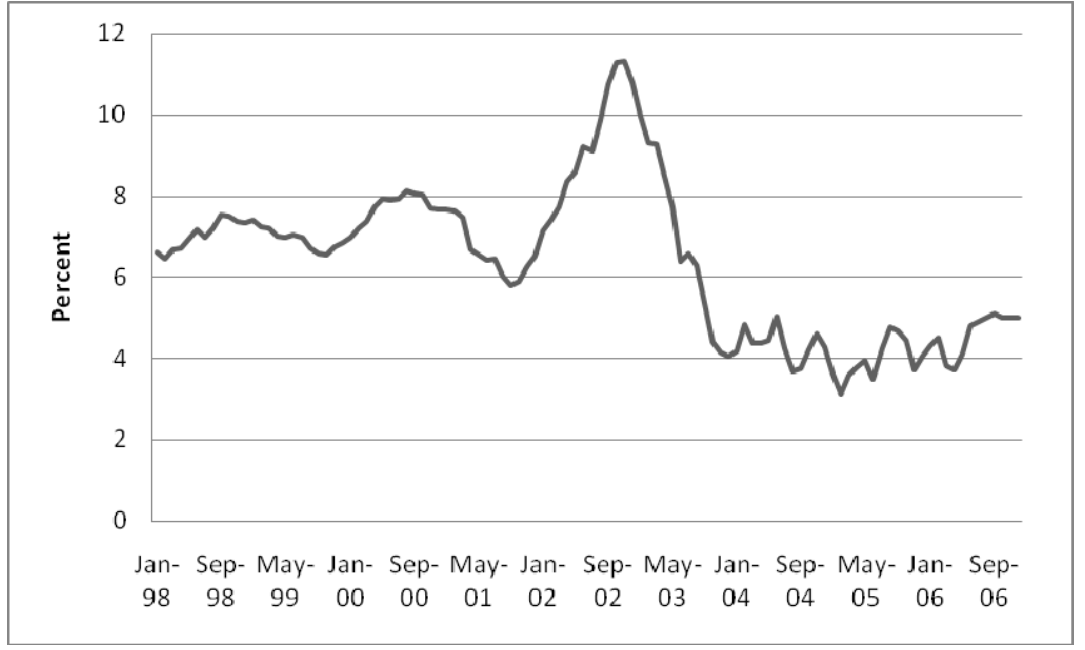

Source: Statistics South Africa

The inflation rate of the CPIX (the CPI excluding interest on mortgage bonds), which started being computed in 1997 and is the basis for the SARB's official inflation target, has also fallen markedly over time. Inflation rose sharply in 2002, reflecting an earlier easing of monetary conditions as well as the pass-through effects of a sudden sharp depreciation in the exchange rate in late 2001 , but the rise was temporary. The increase in monetary policy transparency during the period since 2000 has coincided with a statistically significant negative trend in the inflation rate, notwithstanding the spike in 2002 (see TABLE 6). 
TABLE 6: Inflation trends, 2000-2006

\begin{tabular}{lcc}
\hline & Constant & Time trend \\
\hline CPIX & 8.64 & -0.06 \\
& $(24.68)$ & $(-8.05)$ \\
CPI & 6.83 & -0.04 \\
& $(10.87)$ & $(-3.19)$ \\
\hline
\end{tabular}

* $t$-statistics in parentheses

\section{Source: Author's regressions}

One would expect greater monetary transparency to help anchor inflation expectations and thus to reduce the volatility of inflation. However, inflation is also subject to exogenous shocks that, when they occur, increase volatility. During the period since 1998, the volatility of CPIX inflation showed a trend increase, which is attributable, however, to the period of market turbulence in 2002 and part of 2003 during which inflation volatility rose sharply (see FIGURE 7). In the more recent period (2003-2006), inflation volatility declined over time.

\subsection{Inflation forecasts}

Greater monetary policy transparency can be expected to contribute to greater accuracy in inflation forecasts over time as the reserve bank's intentions with regard to inflation become clearer to the public. (In addition, in South Africa the increase in monetary transparency was part of the framework of inflation targeting that the government announced in 2000 that it would adopt starting 2002.) As with the interest rate forecasts above, a simple measure of the accuracy of inflation forecasts is the absolute value of the differential between the actual inflation outturn for a particular period and the market forecast of inflation for that period made at a previous date. The market forecast can be measured by the mean forecast of the CPIX inflation rate for a given date reported in the Reuters survey of private forecasters at a previous date. The accuracy of 4-quarter-ahead forecasts, for example, can be measured by the difference between the outturn in a given quarter and the forecast for that quarter that was made 4 quarters previously.

The sample period starts in 2000 because that is when the Reuters surveys of market forecasts began. As it happens, this coincides with the period of substantially greater monetary transparency. However, because it does not cover the period before 2000, this sub-section represents a discussion of trends during the period of increasing monetary transparency rather than a comparison of trends before and after greater monetary transparency.

On this basis, CPIX inflation forecast errors declined markedly in size during 2003-2006. FIGURE 8 plots the forecast error in the CPIX inflation rate as measured by the average inflation rate for a given quarter minus the forecast for that quarter made 1 and 4 quarters ago. In FIGURE 8a, which covers the period 2000-2006, the forecast errors at the 1-and 4-quarter horizons have roughly flat and slightly negative trends, respectively, but the trends are not statistically significant. 


\section{FIGURE 7: Inflation (CPIX) Volatility}
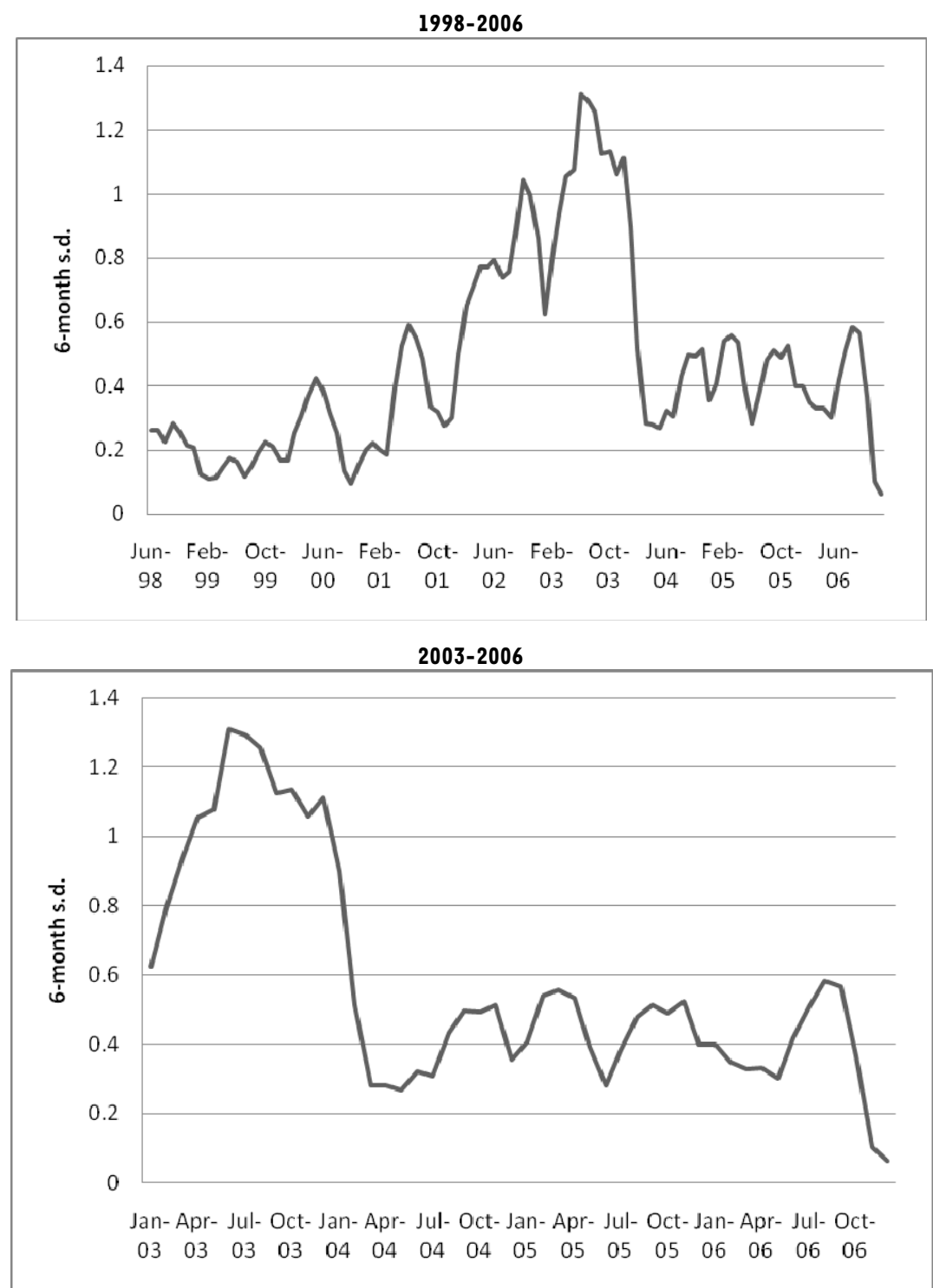

Source: Author's calculations, based on Statistics South Africa CPI and CPIX data

FIGURE 8b, which plots the forecast errors during the more recent period 2003-2006, shows an increase over time in the accuracy of inflation forecasts, as reflected in a negative trend in the forecast errors. The negative trend in the forecast errors was greater at the 1-quarter-ahead horizon than at the 4-quarter-ahead horizon in terms of both size and statistical significance. As a separate point, market forecasters tended to over-predict inflation during the last few years of the sample, as reflected in consistently negative forecast errors from the third quarter of 2003 until the third quarter of 2006. 
FIGURE 8a: CPIX Inflation: Forecast Errors, 2000-2006
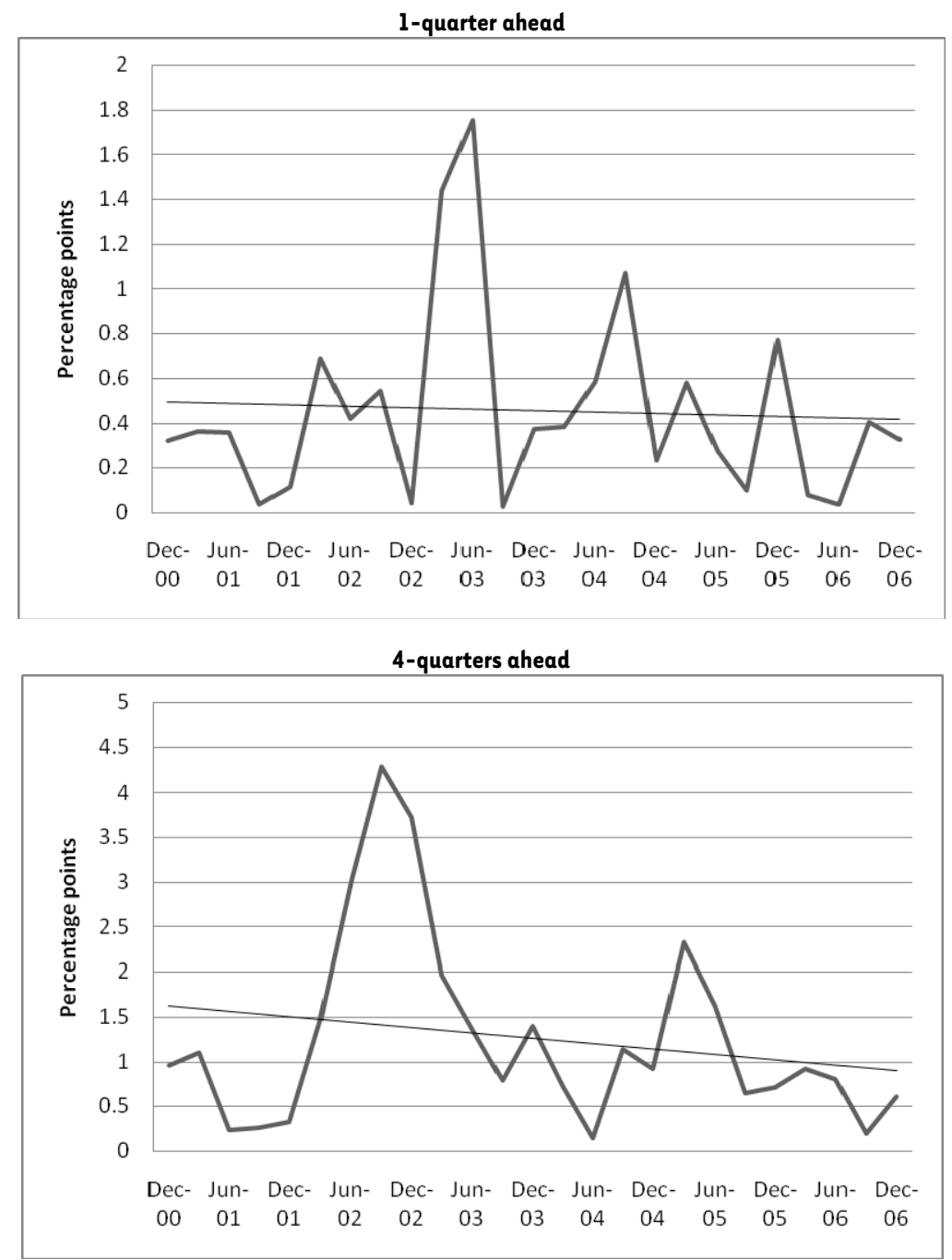

Source: Author's calculations, based on market data and Reuters' forecasts 
FIGURE 8b: CPIX Inflation: Forecast Errors, 2003-2006
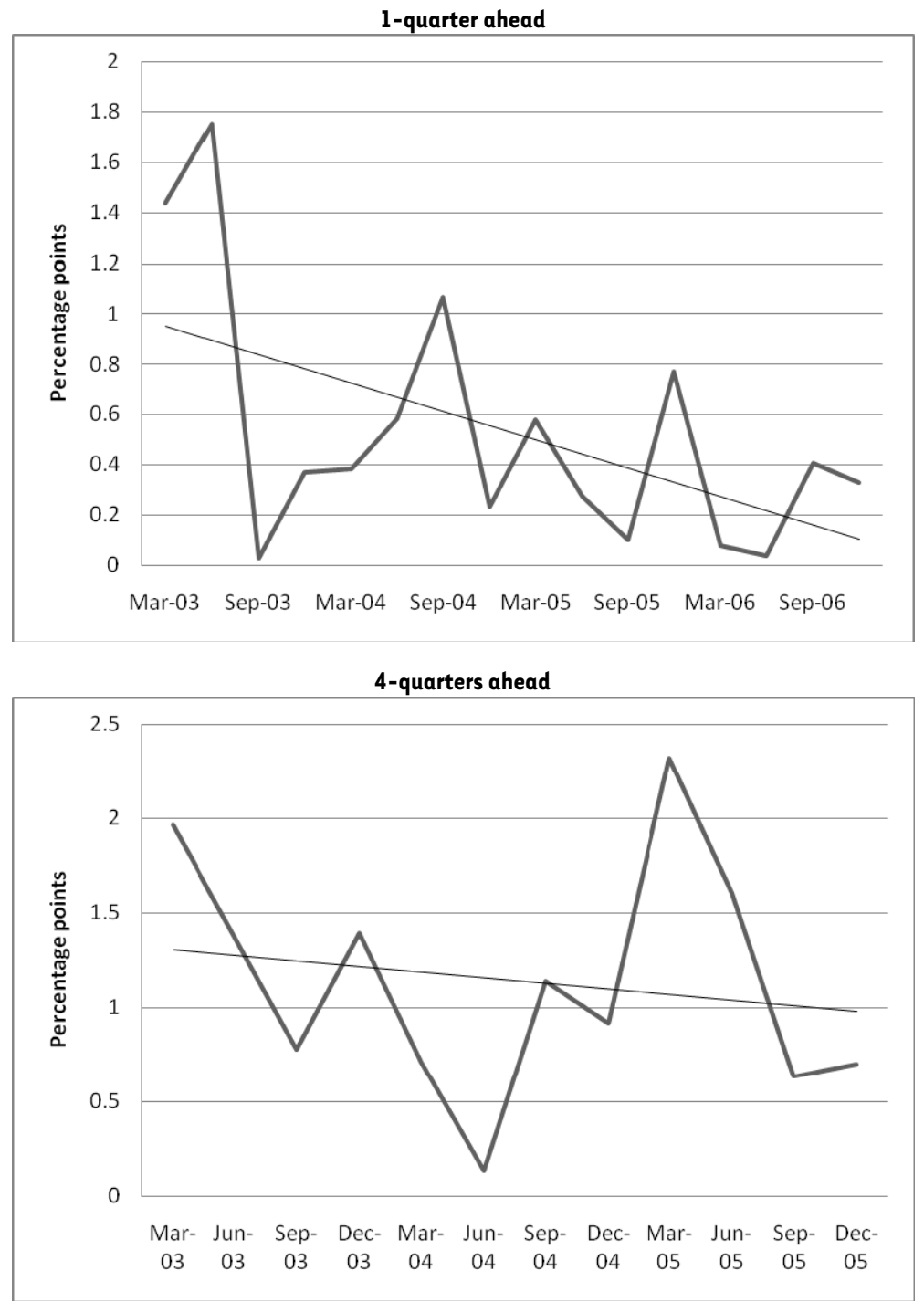

Source: Author's calculations, based on market data and Reuters' forecasts

A relevant question for an open economy with a floating exchange rate, like South Africa, is whether exchange rate shocks account for most of the changes in inflation forecasts. In particular, since exchange rate changes could have a significant impact on inflation expectations, how much of the decline in inflation forecast errors in South Africa have owed simply to changes in exchange rate volatility? Exchange rate volatility in South Africa has historically been sizable. During the period 1998-2006, volatility as measured by the 6-month standard deviation of changes in the nominal effective exchange rate had a slight upward trend (FIGURE 9). 
FIGURE 9: Exchange Rate Volatility

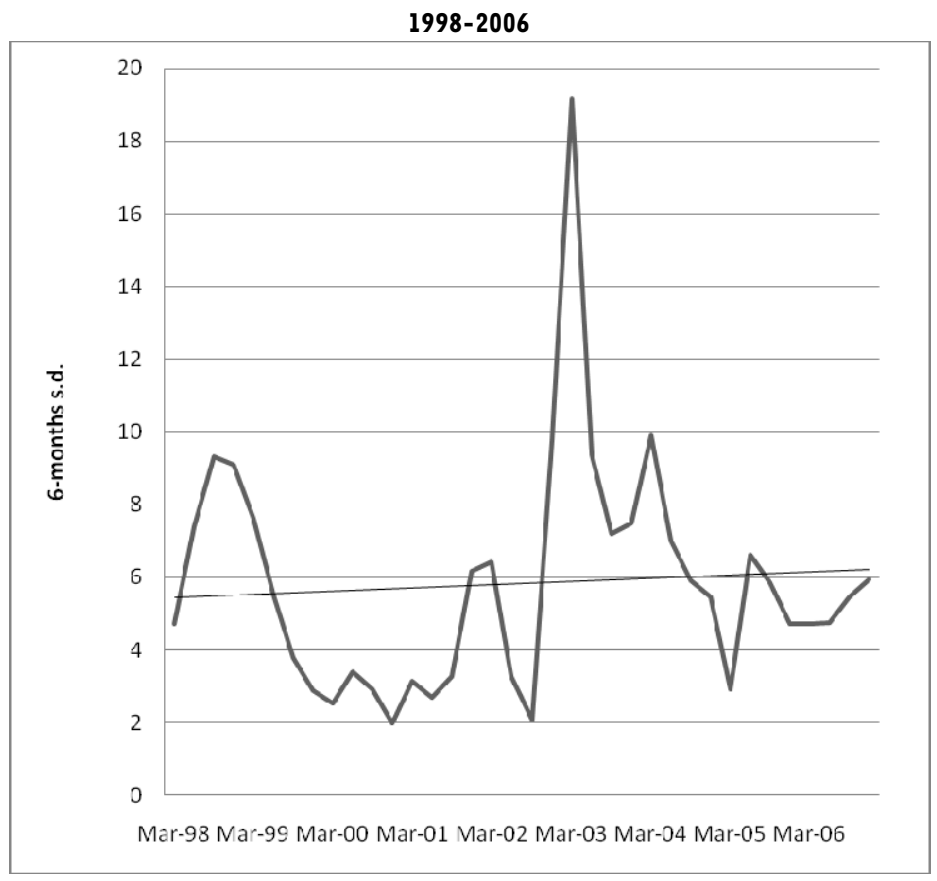

$2003(02)-2006$

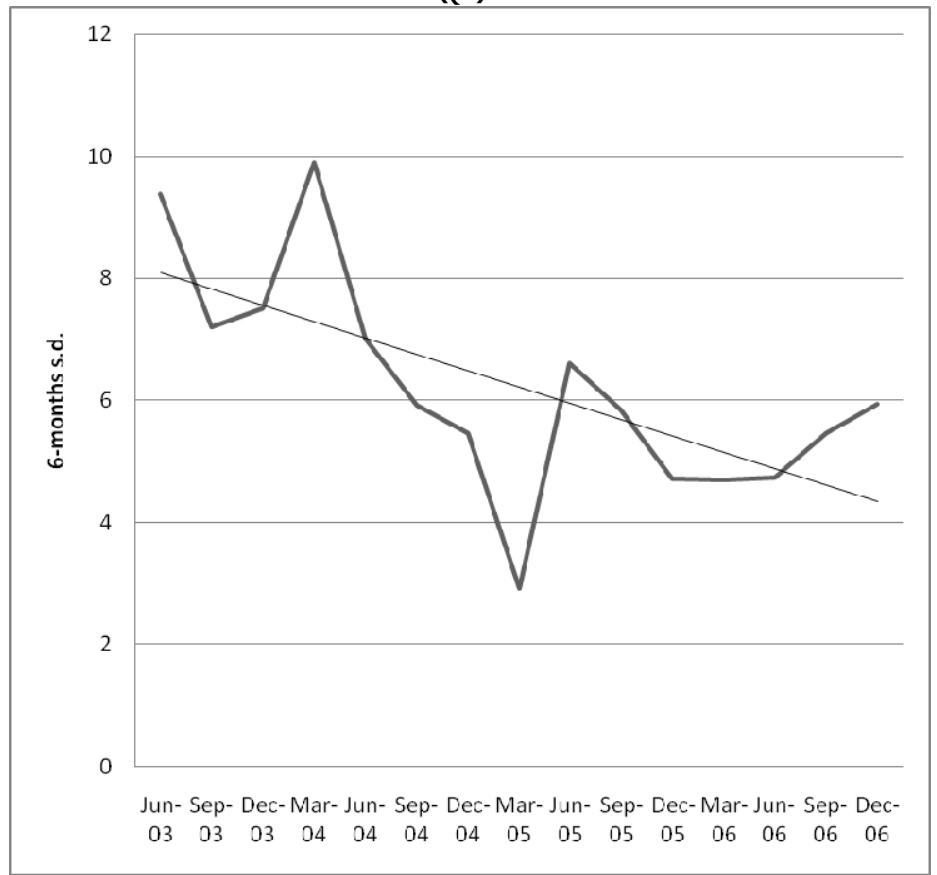

Source: Author's calculations based on data in IMF International Financial Statistics 
The upward trend, however, owed to 3 consecutive quarters of sharply higher volatility associated with the period of market turbulence that started in the $4^{\text {th }}$ quarter of 2002. During the subsequent period, starting in mid-2003, volatility trended downward and for the period December 2003 - December 2006 it was nearly 20 percent lower than for the period March 1998 September 2003.

But exchange rate volatility only partly explains the decline in inflation forecast errors (TABLE 7). At the 1-quarter ahead horizon, exchange rate volatility has a small negative influence on forecast errors. A l-percentage point decline in volatility is associated with a less than 0.1 percentage point decline in the forecast error. At the 4 -quarter ahead horizon, the impact of exchange rate volatility is not statistically significant. The trend in the forecast errors remains negative at both horizons, but it is no longer statistically significant. These conclusions are robust to the use of exchange rate forecast errors, rather than exchange rate volatility, as an explanatory variable (TABLE 8).

TABLE 7: Inflation forecast errors and exchange rate volatility, 2000-2006

\begin{tabular}{ccc}
\hline Constant & Exchange rate volatility & Time trend \\
\hline 1-quarter forecast error & 0.06 & -0.008 \\
0.24 & $(2.61)$ & $(-0.87)$ \\
$(1.32)$ & & \\
4-quarter forecast error & 0.03 & -0.032 \\
1.51 & $(0.41)$ & $(-1.04)$ \\
\hline
\end{tabular}

* $t$-statistics in parentheses

Source: Author's regressions

TABLE 8: Inflation forecast errors and exchange rate (rand/dollar) forecast errors, 2000-2006

\begin{tabular}{ccc}
\hline Constant & Exchange rate forecast error & Time trend \\
\hline I-quarter forecast error & -0.02 & -0.01 \\
0.71 & $(-1.62)$ & $(-0.60)$ \\
$(3.49)$ & & \\
4 -quarter forecast error & 0.00 & -0.03 \\
1.65 & $(0.00)$ & $(-0.94)$ \\
$(2.40)$ & &
\end{tabular}

*t-statistics in parentheses

Source: Author's regressions 
The fact that forecasters use the exchange rate as a key variable in projecting inflation raises the question of whether changes in exchange rate forecast errors significantly influence the accuracy of inflation forecasts. Indeed, exchange rate forecast errors have declined over time in South Africa. However, including them instead of exchange rate volatility as an explanatory variable for inflation forecast errors does not change the above conclusions. The limited role of the exchange rate in explaining inflation forecast accuracy could reflect the fact that exchange rate volatility is only one of the factors that influences forecast errors, and other factors would have to be included in order to account for the decline properly.

Such an investigation is, however, outside the scope of this paper, which only aims to establish the fact of a decline in forecast errors over time. Moreover, exchange rate volatility itself is arguably influenced by the monetary policy framework, among other factors. For example, there is evidence that higher international reserves help to reduce exchange rate volatility (Nowak, Ricci \& Hviding, 2004).

\subsection{Dispersion of inflation forecasts}

The increase in the accuracy of market forecasts of inflation was accompanied by greater unanimity among forecasters, reflected in a reduction in the cross-sectional dispersion of forecasts. The dispersion, defined as the maximum- minus the minimum forecast of the CPIX inflation rate in the Reuters monthly survey of market participants, declined over time at both the 1-quarter ahead and 4-quarter-ahead horizons (FIGURE 10).

The negative trend in the cross-sectional dispersion of forecasts was statistically significant for the 2003-2006 period. It was not significant for the full 2000-2006 period, which includes, as noted, the period of turbulence when forecasts in general performed poorly and were disparate. It should be noted, however, that for judging the impact of monetary policy transparency, forecasts of interest rates, which are closely related to the SARB's policy instrument, are more relevant than those of inflation, which is influenced in the short run by many other factors.

\subsection{Comparison with other macroeconomic forecasts (GDP)}

Might the improvements in interest rate (and inflation) forecasts have nothing to do with monetary policy, but instead just reflect a growing sophistication on the part of private sector forecasters? If this were the case, then forecasts of macroeconomic variables that are less closely and less directly related to monetary policy than are interest rates, such as indicators of real output, should also have improved over time.

The evidence on improvements in real GDP forecasts, however, is less convincing than that on interest rate forecasts. (While it would be useful for the sake of completeness also to examine the trends in forecast quality for other real sector variables, such as manufacturing, industrial production, and retail sales, these forecasts are not available in the Reuters survey on which the analysis in this paper is based.) Overall, the evidence does not contradict the conclusion that the improvements in interest rate forecasts have exceeded those in GDP forecasts. 
FIGURE 10: Dispersion in inflation forecasts, 2000-2006
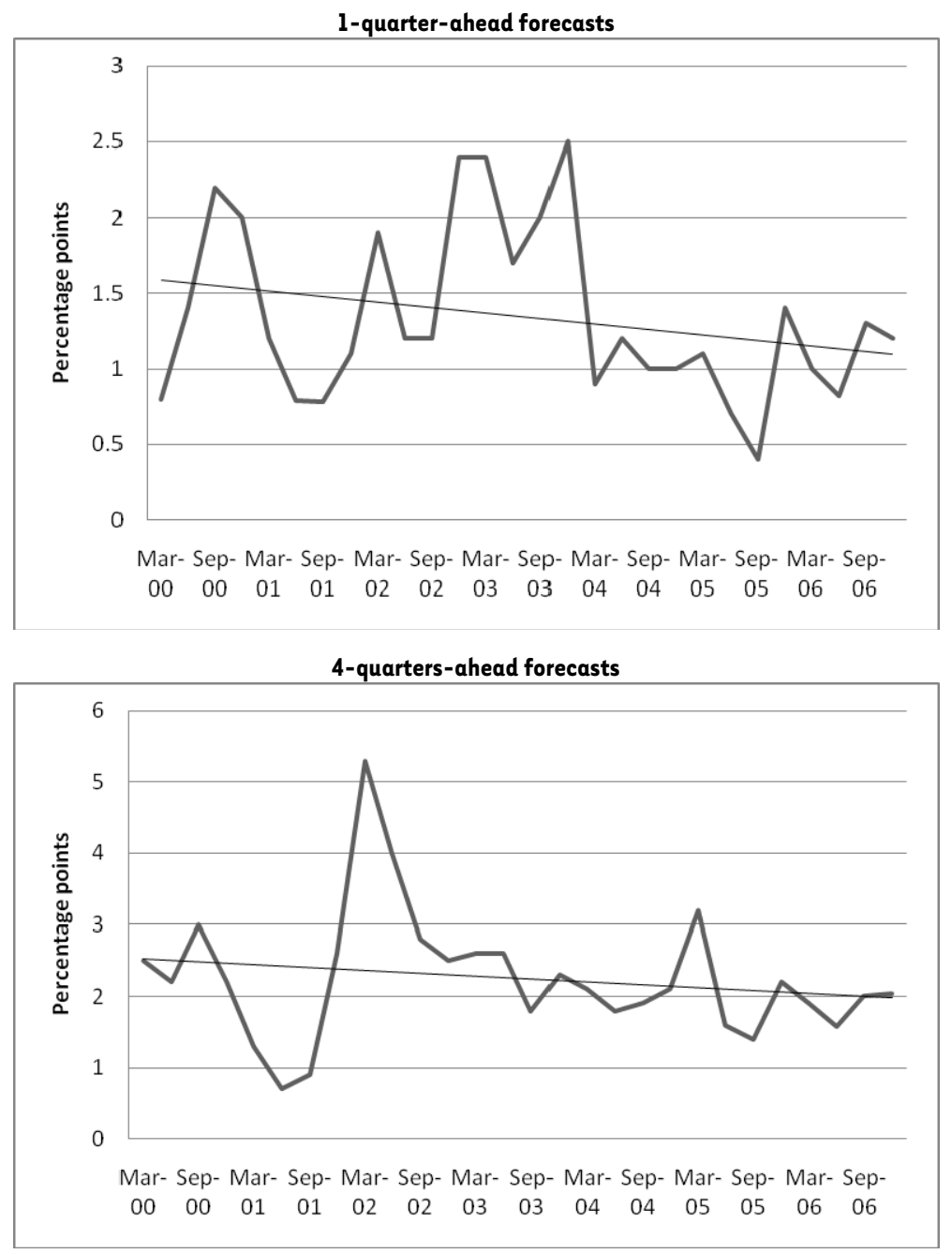

Source: Author's calculations, based on Statistics South Africa CPIX data

FIGURE 11 plots the errors in GDP forecasts, defined as the absolute difference between the actual outturn for real GDP growth in a given quarter minus the forecast for that quarter 1 and 4 quarters ago over the period 2000-2006. 
FIGURE 11: GDP forecast errors, 2000-2006

1-quarter-ahead errors
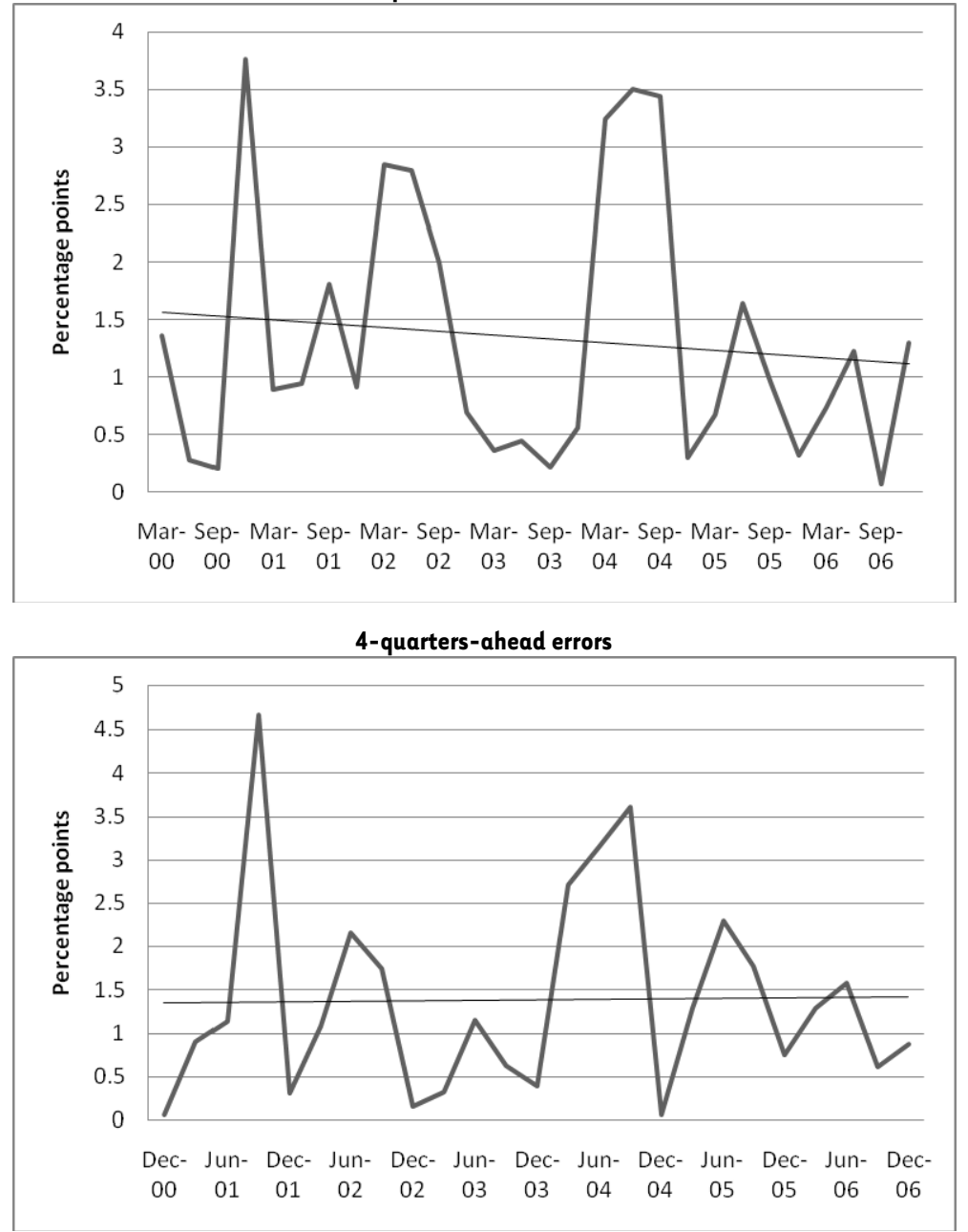

Source: Author's calculations, based on market data (see Appendix)

The forecast error did not change appreciably at either horizon. The error had a slight negative trend at the 1-quarter horizon and a slight positive trend at the 4-quarter horizon but neither of these trends was statistically significant.

Excluding the period of market turbulence in 2002, when economic forecasts in general performed badly, and focusing instead on the period 2003-2006 changes the conclusion only slightly with regard to GDP forecasts (FIGURE 12). 
FIGURE 12 GDP forecast errors, 2003-2006

1-quarter-ahead errors

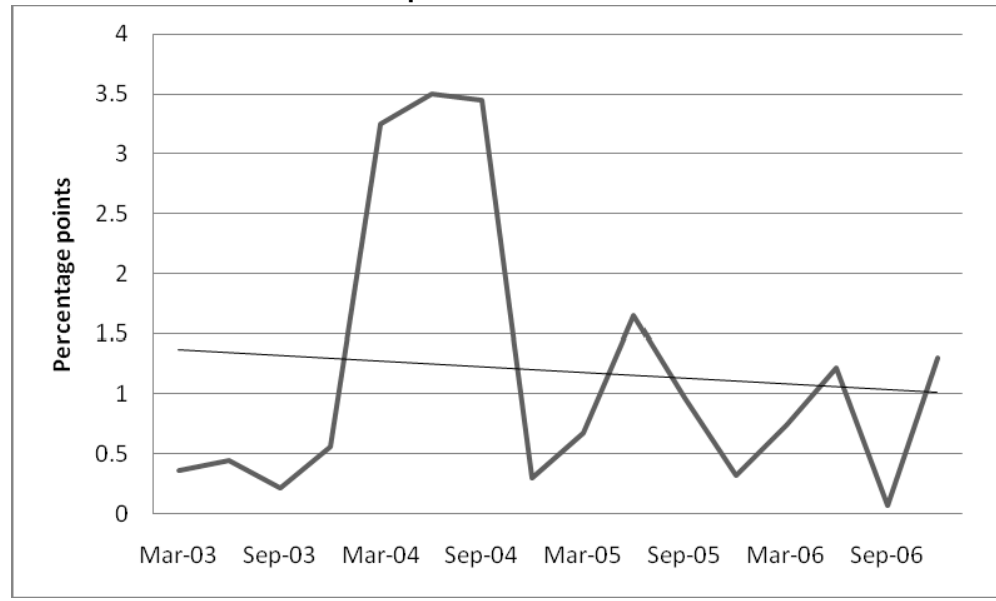

4-quarters-ahead errors

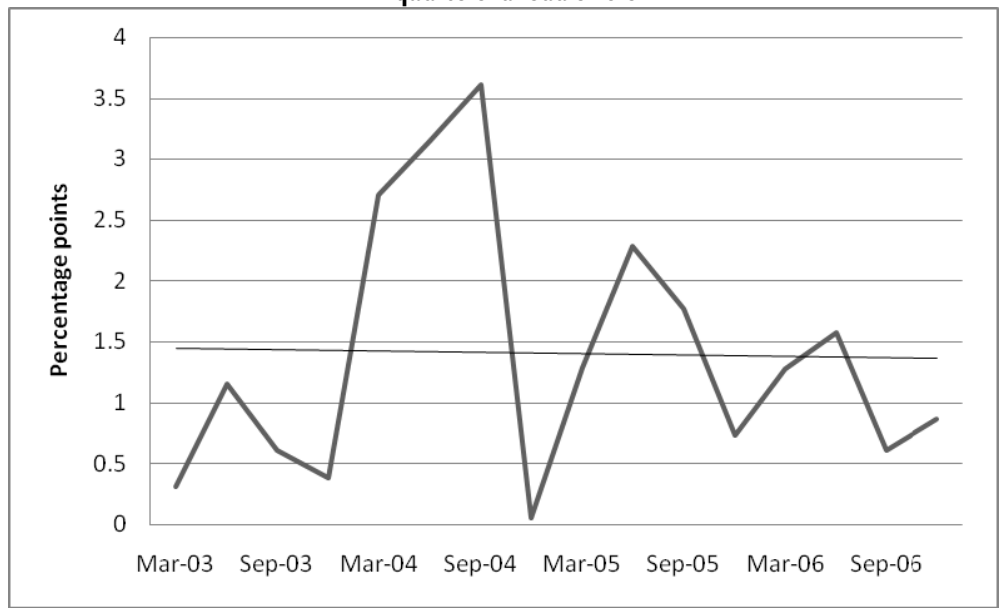

Source: Author's calculations, based on market data (see Appendix)

During 2003-2006, forecast errors declined at both the 1- and 4-quarter horizons (the trends were negative) although the decline was not statistically significant. The cross-sectional dispersion of GDP forecasts declined at both the 1- and 4-quarter horizons, and the decline was statistically significant, suggesting that there was some increase in unanimity among forecasters (FIGURE 13). 
FIGURE 13: GDP forecast dispersion, 2000-2006

(1-quarter-ahead forecast)

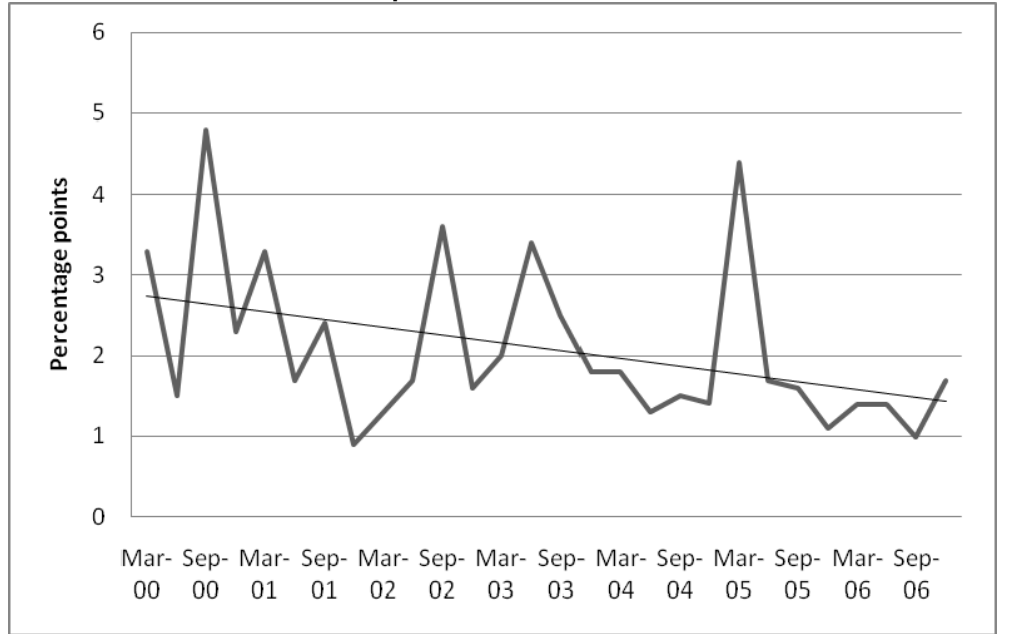

(4-quarters-ahead forecast)

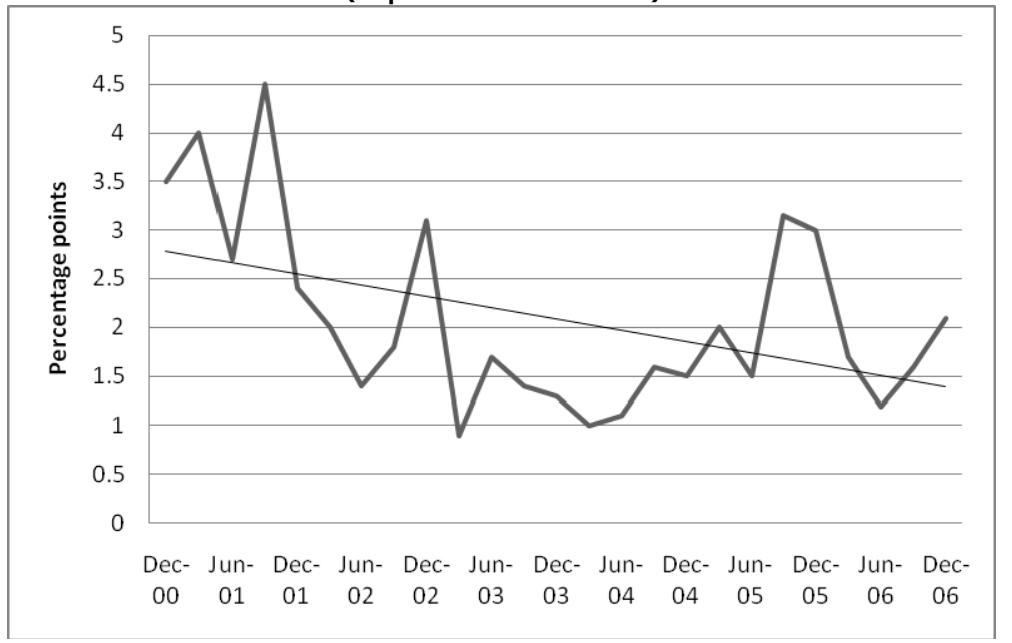

Source: Author's calculations, based on market data (see Appendix)

\section{CONCLUSION}

This paper has shown that private sector financial forecasts in South Africa have improved in recent years. The accuracy of interest rate forecasts has increased, as reflected in a negative trend in forecast errors; forecasters have been less surprised over time by MPC announcements; and forecasters have become less diverse in the cross-sectional dispersion of their forecasts. Inflation forecasts have also become more accurate over time.

The improvements in interest rate and inflation forecasts are greater than those in real GDP forecasts, suggesting that monetary policy transparency is likely to have played a role. In future 
research, it would be useful to examine the role of alternative factors, such as exchange rate volatility and monetary variables, in accounting for the decline in inflation forecast errors over time.

\section{Acknowledgement}

I am grateful to Eric Swanson for the idea discussed in this paper and to Saul Lizondo, Alfredo Cuevas, Thomas Harjes, Sean Nolan, Athanasios Vamvakidis, and two anonymous referees for helpful comments; to Marisa Fassler and Tebogo Dintwe for providing the data on macroeconomic forecasts and interest rates; and to Leighton Harris for assistance with assembling the data set.

\section{REFERENCES}

Aron, J. \& Muellbauer, J. (2005). Review of Monetary Policy in South Africa during 1994-2004. Paper presented at a conference on South African Economic Policy under Democracy: a 10-Year Review at Stellenbosch University, October 2005.

Ball, L. \& Sheridan, N. (2003). Does Inflation Targeting Make a Difference? in Bernanke, B. (ed.), Inflation Targeting. Chicago: University of Chicago Press.

Bernanke, B., Laubach, T., Mishkin, F. \& Posen, A. (1999). Inflation Targeting: Lessons from the International Experience. Princeton: Princeton University Press.

Bhundia, A. \& Ricci L. (2005). The Rand Crises of 1998 and 2001: What have we learned? in Nowak, M. (ed.), Post-Apartheid South Africa: The First Ten Years, Chapter 10. Washington: International Monetary Fund.

International Monetary Fund (IMF) (2002). South Africa: Staff Country Report for the 2002 Article IV Consultation. Washington, DC: International Monetary Fund.

Mboweni, T. (2004). The Monetary Policy Framework of South Africa. Address at International Investors' Conference, Sun City, 24 March 2004.

Nowak, M., Ricci L. \& Hviding K. (2004). Can Higher Reserves Help Reduce Exchange Rate Volatility? IMF Working Paper No. 04/189. Washington: International Monetary Fund.

Poole, W., Rasche, R. \& Thornton, D. (2002). Market Anticipations of Monetary Policy Actions. Federal Reserve Bank of St. Louis Economic Review, July/August, pp. 65-94.

Reuters, various years, Monthly Surveys of South African Financial Institutions.

Swanson, દ. (2006). Have Increases in Federal Reserve Transparency Improved Private Sector Interest-Rate Forecasts? Journal of Money, Credit, and Banking, 38(3), pp. 791-819.

Van der Merwe, E.J. (2004). Inflation Targeting in South Africa. South African Reserve Bank Occasional Paper No. 19, July 2004. 


\section{Appendix : Data sources}

- Data on the Johannesburg Interbank Rate (JIBAR) and forward rate agreements (FRA) were obtained from the JP Morgan data source, Data Query that is compiled from daily closing rates.

- Data on the cross-sectional dispersion of private sector interest rate and inflation forecasts were obtained from the Reuters monthly survey of 14 financial market institutions. The Reuters survey covers quarterly forecasts. The dispersion was calculated as the maximum minus the minimum forecast for (i) the prime rate and (ii) the CPIX inflation rate, at both the l-quarter ahead and the 4quarters-ahead horizons.

- Data on the private sector forecasts of CPIX inflation and GDP growth were taken from the Reuters monthly survey of 14 financial market institutions. 